\title{
THE MODERATING EFFECTS OF GENDER, CAREER, MORAL MINDSET ON THE RELATIONSHIP BETWEEN THE GRADUATE ATTRIBUTES AND READINESS FOR EMPLOYABILITY AMONG ENGINEERING COLLEGES GRADUATES IN OMAN
}

\author{
Masoud Rashid Al Hinai \\ PhD Research Fellow \\ Faculty of Business and Accountancy \\ University of Selangor \\ 40000 Shah Alam, Selangor Darul Ehsan, Malaysia \\ E-mail: alhinai6602@gmail.com \\ Dr. Abul Bashar Bhuiyan \\ Associate Professor \\ Faculty of Business and Accountancy \\ University of Selangor \\ 40000 Shah Alam, Selangor Darul Ehsan, Malaysia \\ E-mail: bashariuk@gmail.com \\ Dr. Nor AzilahHusin \\ Associate Professor \&Deputy Dean \\ Faculty of Business and Accountancy \\ University of Selangor \\ 40000 Shah Alam, Selangor Darul Ehsan, Malaysia \\ E-mail: nor_azilah@unisel.edu.my
}

\begin{abstract}
The Omani higher education system has enlarged noticeably since 1970 both in the number of students and in the infrastructure. As a result, there has been a wide investment to provide quality higher educational institutes capable of providing suitable graduates to fulfill the requirements of both public and private sectors with a focus on females to assure equal gender educational and career opportunities chances. Therefore, graduates' readiness for employability has become a major issue for Higher Education Institutes (HEIs) in Oman due to the growing concern from governments and industries on the quality of the graduates. Therefore, the main objective of the current study is to develop a conceptual framework for the graduate readiness for employability and incorporates the graduate attributes including human capital attributes, social capital attributes, individual attributes, institution-related attributes, and active learning attributes moderated by gender, career, and moral mindset among Engineering Graduate in Oman. The study uses available sources of existing literature based on the four main keywords 'higher education', 'graduate attributes 'or 'readiness for employability, and 'skills gaps in
\end{abstract}


Oman'. The study also justified by the following theories which are human capital; education and economy development; behavior theory; and motivation theory. The literature utilized for this study covers the latest literature (from 2013 to 2020) extracted from Google Scholar, ProQuest, and Scopus, and other online resources. Based on the summary findings, the study develops a framework that analyses the effects of influential factors on the graduate readiness for employability that will be considered as an empirical study on the graduates of the engineering colleges in Oman. Moreover, the study also concluded that there are moderating effects of gender, moral mindset, and career mindset on the influence factors and the graduate readiness for employability among Omani engineering colleges' students. The results of the study will fill the gap in understanding the main factors affecting the attainment of graduates' readiness for employability skills in Oman. The study recommends justifying this conceptual framework by empirical data from the Engineering Graduate in the Higher Education Institutes (HEIs) and draws a policy guideline for ensuring of readiness of engineering graduates for employability in the HEIs in Oman.

Keywords: Active Labs, Attributes, Capital, Employability, Gender; Graduate, Higher Education, Mindset, Skills.

\section{INTRODUCTION}

Higher education (HE) is considered an important issue for the development of the social life and the growth of the economic sector of the Sultanate of Oman (Al-Marjan, 2004). The education system in Oman has gone through two major stages. The first stage was to enhance the quantity of education in the era commenced between 1970 and 1995. While, the second stage which took place after 1996, intended to reform the Higher Education (HE) quality and enhance the skills and competence of the graduates (Funsch, 2015).

The HE system in the Sultanate of Oman is supervised by different entities that set the procedures, administrations, and tactics plans for approval by the Council of HE (CHE) (AlHarthi, 2011). Due to having different entities, the HEIs in Oman have several setbacks concerning the tactics plans, the workplace requirements, and the national economy requirements of skilled graduates (Al-Lamki, 2002).

One of the most important challenges is how to provide a continuously changing requirement of skilled degree graduates to industries. Despite the attempts of academia to enhance the graduates' readiness for employability skills, many work providers are not gratified with the new graduates' quality (Lim, Lee, Yap, \& Ling, 2016; Yang, Cheung, \& Fang, 2015). Worldwide, graduates' readinesses for employability skills gaps are noticed by many studies. For example, in Australia, there is an indication of about $22.4 \%$ of health employers reported having problems when hiring new graduates for not having the required readiness for employability skills (Messum, Wilkes, Jackson, \& Peters, 2016). Similarly, 64\% of Indian engineering work providers reported that they are not satisfied with their fresh recruited graduates (Blom \& Saeki, 2011). Furthermore, $73 \%$ of Uzbekistan firms have reported having substantial problems with new graduates because they lack the desired employment skills (Ajwad et al., 2014). Additionally, studies done on different sectors in India concluded that up to $60 \%$ of industries stated that new graduates who joined the labor force lack the essential soft skills for succeeding at their firms and $82 \%$ mentioned that there is a big skills gap present between what industry requires and graduates' possess (Deepa \& Seth, 2013). 
As a result of the Skills Gap of the HE graduates, the unemployment rate among the Omani graduates is high. Another research concluded that many Omani youth graduates spend more than three years to find a job (NCSI, 2015). Also, in a study administered by the Ministry of Higher Education, the findings indicated that among 12,551graduates, 53\% of the students were still unemployed (Ansari \& McGlade, 2018). To explore the results of unskilled graduates, one study found that the graduate unemployment rate is as high as 19\% (OMAN, 2011). Other studies showed that the number of unemployed people is 49,000 among them 14,980 are HE graduates (Ansari \& McGlade, 2018). The number of job seekers by the end of 2016 was 43,838 (NCSI, 2017). The latest data obtained from E-Census (2020) indicated that the total job active seekers is 65,438 with 24,401 HE graduates (E-Census, 2020). Other researchers claim that the spread of unemployment among graduates is because of their skills Gap. They concluded that the HEIs are failing to provide the industries with skilled graduates. As a result of this shortfall of the HE system to produce highly qualified graduates, the work providers continued to recruit highly skilled workers internationally (Coenjaerts, Ernst, Fortuny, Rei, \& Pilgrim, 2009; Joshi \& Ghosal, 2009; Randeree, 2009; Swailes, Al Said, \& Al Fahdi, 2012). "The World Economic Forum on the Global Competitiveness (2014-2015)", has emphasized the fact that the second most obstacles to investment in Oman is unskilled employee graduates.

Therefore, this study aims to determine a readiness for employability frame work which identifies the essential graduates' readiness for employability required skills which identified as; soft skills consisting of Critical or analytical thinking, problem solving skills, Communication skills, lifelong learning and information literacy, Team-working skills, Professional ethics and morality, Entrepreneurship skills, and Leadership skills (Adnan, Daud, Alias, \& Razali, 2017; Al-Azri, 2016; Anastasiu et al., 2017; Belwal, Priyadarshi, \& Al Fazari, 2017; Craps et al., 2017; Evans, Davis, \& Wheeler, 2017; Finch, Hamilton, Baldwin, \& Zehner, 2013; Gupta, Singh, \& Kaushik, 2018; Lane, 2017; Moore \& Morton, 2017; Neisler, Clayton, Al-Barwani, Al Kharusi, \& Al-Sulaimani, 2016), proficiency of English (Al-Lamki, 1998, 2006; Al-Mahrooqi, 2012; AlMahrooqi \& Denman, 2016; Allen \& De Weert, 2007; Arkoudis, Baik, Bexley, \& Doughney, 2014; Manoharan \& Arockiam, 2017), and technical industrial skills (Anastasiu et al., 2017; Belwal et al., 2017; Cooper, Gallagher, Collins, \& Shahir, 2015). Also, it intends to address the Graduates' attributing factors that may cause the misalignment of skills Gap provided by the HEIs and the workplaces required skills that influence engineering graduates' readiness for employability in Oman consisting of human capital, social capital, and the individual attributes (Clarke, 2018), institution-related attributes (Jackson, 2014), and active learning attributes (Hassan \& Puteh, 2017). Finally, it analysis the moderating effect of gender(Strachan, Peixoto, Emembolu, \& Restivo, 2018), career, and moral mindset (Jones, 2017).

In such circumstances, it the timely initiative, find scope to provide quality higher educational institutes capabilities for ready skill graduates to fulfill the requirements of both public and private sectors with a focus on females to assure equal gender educational and career opportunities chances. Therefore, graduates' readiness for employability has become a major issue for HEIs in Oman due to the growing concern from governments and industries on the quality of the graduates. This approach to graduate readiness for employability intends to design a framework that incorporates the graduate attributes including human capital attributes, social capital attributes, individual attributes, institution-related attributes, and active learning attributes moderated by gender, career, and moral mindset. This unique graduate attributes framework is intended to be used as an Empirical Study on the Engineering Graduate readiness of employability in Oman. 


\section{BACKGROUND OF THE STUDY}

\section{Concept of graduate readiness for employability}

Graduate readiness for employability has been the main concern of many and newly published studies indicating that readiness for employability is highly considered by researchers, academia, and the industries (Finch et al., 2013; Smith, Ferns, \& Russell, 2014; Sumanasiri, Yajid, \& Khatibi, 2015).

A newly widely used definition of graduates' readiness for employability combines the weight of generic soft skills and graduate attributes. Such a definition indicates the importance of industrial and work skills attainment (Jackson, 2016).

"A set of generic softer skills, in particular, personal attributes that can be summed up as a positive attitude are critical to being employable. A positive attitude encapsulates characteristics such as a willingness to take part and openness to new activities and ideas. It underpins and links together the other key capabilities"(Jackson, 2016).

Since graduate readiness for employability refers to the ability of graduates' gaining the most generic academic skills and specific employability skills (Stiwne \& Alves, 2010). Therefore, this definition of Graduate Readiness for Employability emphases highly the importance of graduates' attributes, and the attainment of technical industrial work skills and knowledge over academic performance.

\section{Technical Skills}

Hard skills are known as the technical skills required to carry technical works and also the administrative procedures related to an industry's core work. Hard skills are the occupational skills required by a job or any other technical activities such as for "equipment operation, computer protocols, safety standard, financial procedure, and sale administration". (Chaturvedi, Yadav, \& Bajpai, 2011).

\section{Soft Skills}

Soft skills are the skills required to perform hard skills such as interpersonal communication, critical thinking, work ethics, and creativity. According to Abdullah-Al-Mamun (2012), soft skills play essential roles in deciding the success of any person in his occupation. He added that "people with a solid command of soft skills can think of their feet, solve problems, lead a group through teamwork exercises, give critical feedback, motivate fellow employees, and set an example" (Abdullah-Al-Mamun, 2012).

Besides, Lazarus (2013), defined soft skills as the preferable attributes required for employment which are not based on acquired knowledge like sensibility, common sense, flexibility, and positive attitude (Arthur Lazarus, 2013).

Also, Parsons (2008), stressed that soft skills play a major role when seeking employment. He emphasized the personality traits, soft skills, which enhance the employability of people (Parsons, 2008). Hurrell and Scholarios (2014) defined soft skills as "nontechnical and not reliant on abstract reasoning, involving interpersonal and intrapersonal abilities to facilitate mastered performance in particular contexts" (Hurrell \& Scholarios, 2014). Therefore, "soft skills represent a dynamic combination of cognitive and meta-cognitive skills, interpersonal, intellectual and practical skills and ethical values. Soft Skills help people to adapt and behave positively so that they can deal effectively with the challenges of their professional and everyday life" (Rao, 2018). 


\section{Concept of Human Capital Attributes}

Human capital Attributes acknowledged as essential elements for graduates' readiness for employability. Many researchers have argued the magnitude to which generic skills, soft, and technical are considered to be interchangeable from HEIs to the industries, or among employers (Hinchliffe \& Jolly, 2011; Kalfa \& Taksa, 2015). However, skill learning is an essential part of higher education. General required competencies, including problem-solving, critical thinking, or team skills represent a higher order thinking type of skills that are expected to be acquired by $\mathrm{HE}$ graduates. They are considered to be an essential part of graduates' identity. Those skills are linked strongly with career expertise especially for entering highly sophisticated professions such as engineering or medicine. Therefore, Human capital attributes are an essential part of graduate employability (Heijde \& Van Der Heijden, 2006).

\section{Social Capital Attributes}

There is strong evidence that social capital attributes such as the quality and rank of university attended and the specialization attained to have a strong impact on employment outcomes (Holmes, 2013). For some researchers, the reputation of awarding university has a strong impact on graduate employability (Finch et al., 2013). Also, some other studies founded that the status of the rewarding HE university influenced the recruiting process which means that rewarding HEIs affect the readiness of the employability of its graduates (Okay-Somerville \& Scholarios, 2014).

There are also indications that it impacts perceived employability (Okay-Somerville \& Scholarios, 2015; Rothwell, Herbert, \& Rothwell, 2008). As a result, networking as a key component of social capital attributes strongly influences the awareness of career information which in return affects positively graduates' readiness for employability (de Janasz, Forret, Haack, \& Jonsen, 2013; Forret \& Dougherty, 2004). In conclusion, social capital attributes when combined with human capital attributes and other factors such as individual attributes, and modern active learning environment can greatly improve graduates' readiness for employability.

\section{Individual attributes}

The aspect of individual attributes has recognized as an essential part of career success (Fugate \& Ashforth, 2003). For any graduates having adaptability and flexibility attributes help the graduate to deal with any required change and also make the graduate ready to deal with future career changes and therefore he can enhance his job desired outcomes (Fugate, Kinicki, \& Ashforth, 2004; Heijde \& Van Der Heijden, 2006). Individual attributes affect the aim of employability (Okay-Somerville \& Scholarios, 2015). Bridgstock (2009) in his paper "The graduate attributes we've overlooked: Enhancing graduate employability through career management skills", split career skills into as "self-management skills, and career-building skills". Self-management skills consist of the individual attributes of personnel's' "values, attitudes, abilities, aptitudes, interests, and work-life balance". While career-building skills help graduates to sail and progress in their careers (Bridgstock, 2009). Therefore, graduates are desired to attain the adaptability and flexibility attributes for their future readiness for employability.

\section{Active Learning Attributes}

Active Learning Attributes consisting of Computer Based Training (CBT), Simulators, and Virtual Learning Equipment (VLE) is considered an interactive learning environment. They are 
considered a close resemblance to real-world environments. This equipment uses a high-fidelity virtual environment to enhance learning. The use of an active lab environment is a relatively new method and therefore, its suitability must be investigated as an adequate tool in delivering transferable training skills (Adams et al., 2008; Fitzgerald et al., 2011). Another research has pointed out that the workplace environment and the use of hypermedia technologies are valuable sources for workers and students training (Conrad, 2008). Also, Boyd (2017) investigated the effectiveness of online interactive simulations in the improvement in learners' ability to apply critical thinking skills in a dangerous work environment. He found that the implementation of the interactive simulation was as effective as training in real live equipment (Boyd, 2017).

\section{METHODOLOGY OF THE STUDY}

The methodology of this paper is done by conducting extensive secondary data analysis. The related literature and papers from the years of 2014 until the present are collected and then summarized. A meta-analysis technique was then conducted to determine the study framework. The primary at a later stage will be collected from Omani engineering students who graduated or in the final year whether employed or seeking employment both males and females. The study utilizes simple random sampling and its framework is designed based on three teaching and learning theories which are human capital; education and economy development; behavior theory; and motivation theory. The study period covers 5 years (from 2015 to 2020). The literature utilized for this study covers the latest literature (from 2013 to 2020) extracted from Google Scholar, ProQuest, and Scopus. The four main keywords used were 'higher education', 'graduate attributes ', 'readiness for employability, and 'skills gap in Oman.

\section{EMPIRICAL REVIEW FINDINGS}

Graduate readiness for employability is the main driver for HEIs all over the world. Since the last two decades of the 20th, governments and employer's groups have put high pressure on HEIs to provide evidence of the effectiveness of their higher education programs in providing ready to work graduates. From an academic perspective, there is a concern about the effectiveness of HEIs used strategies in developing transferable employability skills into their students. Holmes (2013) analyzed the ways universities deliver graduate employability required skills. He analyzed three influencing factors that affects graduate employability. Those factors are the human capital factors, social capital factors, and the individual behavior factors (Holmes, 2013). He proposed an employability framework consisting of the above factors as main independent variables and contains for the human capital; skills, competencies and work experience, for social capital; network, social class and university ranking and the individual behavior; career self-management and career-building skills.

Other study emphasizes essentially self-perception for graduates' employment success (individual attributes). They have a different definitions for employability to be based on the individual's perception of the possibility of getting and sustaining employment (Vanhercke, De Cuyper, Peeters, \& De Witte, 2014). Clarke (2018) determined an integrated adding another variable to include an employability gap called the labor market variable which is consisting of both the demand of workers and the supply of available workers in the labor market. This new model of graduate readiness for employability combines what he believed as the influencing factors for graduate employability which consisted of human capital, social capital, and individual behaviors and their attributes towards employability taking into account the labor 
market contribution which in total influence the graduate readiness for employment as shown in Figure 1 (Clarke, 2018).

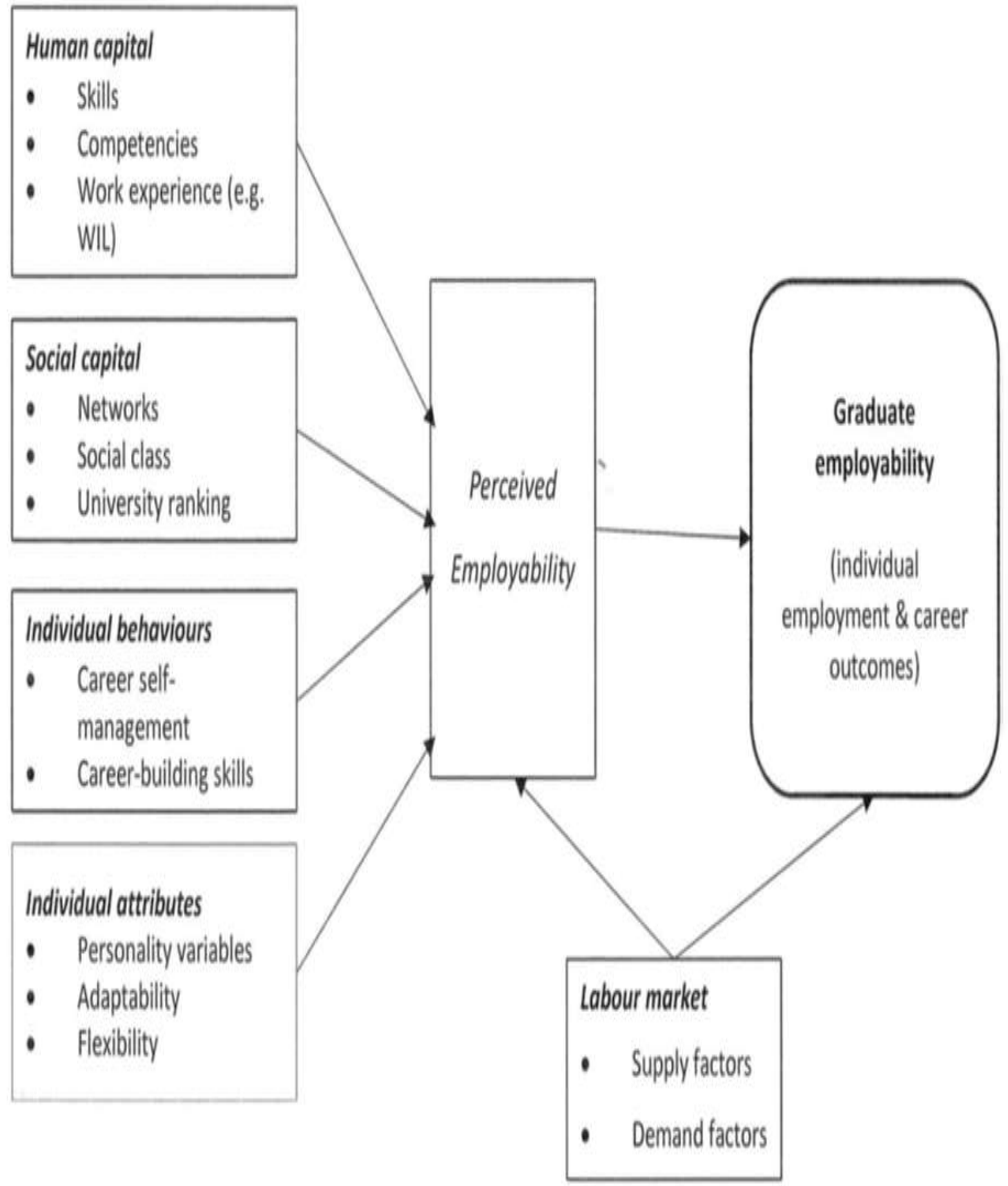

Figure 1. An integrated model of graduate employability (Clarke, 2018) 
There are other factors also influence graduate readiness for employability such as institution-related factors including course quality, graduate identity, academic reputation, pregraduate experience, and job-specific functional skills (Finch et al., 2013). Another important factor is the utilization of an active learning environment for delivering technical industrial related skills. Several empirical studies analyzed the importance of active learning in teaching practical competencies to enhance the quality of engineering graduates for their readiness of employability such as online learning, blended learning, collaborative learning, laboratory learning, and interactive learning (Shetty \& Xu, 2018), computer programs, Computer Based Training (CBTs), Virtual Learning Environment (VLE) and simulators (Hassan \& Puteh, 2017). Moreover, many researchers believed that other factors such as Gender (Mansour, 2018), Career mindset (Rozan \& Zibarzani, 2018), and Moral mindset (Brewer, 2018) have a direct influence in the implementation and attainment of graduate readiness for employability skills at the HEIs.

\section{Theoretical Justifications}

Study theoretical framework was conducted based on three teaching and learning theories which are human capital (Schultz, 1963); education and economic development (Breton, 2012); behavior theory (Liska, 1984); and motivation theory (Kapp, 2012). The expression of human capital is used to indicate the investment in the activities of HE education and work placement that frame the graduate's capabilities and in return enhance his income (Slaughter, Taylor, \& Rosinger, 2015). Considering the Oman case, the HCT theory is used to describe the following expectations; Attainment of graduates' readiness for employability skills is the responsibility of the formal education, Educated graduates must have higher selection priority for employment, and finally, higher-income payments depends highly on graduates' productivity (Al-Harthi, 2011).

\section{DEVELOPMENT OF THE CONCEPTUAL FRAMEWORK}

The present study developed a conceptual framework based on the literature gap and then justified with most relevant theories to solve the Gap existing among HE Engineering graduates' skills and the required skills by the industries in Oman.

The proposed readiness for employability framework can be used to study and analyze the level of readiness for employability of Omani HEIs engineering graduates, the effects of the graduate attributes in the engineering graduates' readiness for employability, and further analyses the moderating effects of gender, career and moral mindset. Such framework can be drawn to assess HEIs in Oman and researchers to identify the required employability skills, understand the most influenced attributes in the graduates' readiness for employability, and draw a deep knowledge on the responsibility of the gender of students and their career and moral mindset in the attainment of readiness for employability skills.

The independent variables of this study are the Graduates Attributes consisting of Human Capital Attributes, Social Capital Attributes, Individual Attributes, Institutional Related Attributes, and Active Learning Attributes (Chan, Fong, Luk, \& Ho, 2017; Clarke, 2018; Hassan \& Puteh, 2017; Holmes, 2013; Jackson, 2014; Shetty \& Xu, 2018; Vanhercke et al., 2014). 


\section{IV}

\section{Human Capital Attributes \\ Adaptation skills, Leadership skills, Motivational Mindset, Ethical and moral issues, \\ Team-work orientation, and \\ Communication skills}

\section{Social Capital Attributes}

Social team building activities including language club, community club, and communication club. Extra curriculum participation Social welfare participation

\section{Individual Attributes}

Personal planning, career orientations, class attendance, family motivation, the parents' career positions, academic excellence, and financial sources of study

\section{Institution Related Attributes}

Institutional policies, classroom environment, syllabus and course curriculum, teaching material, teaching Quality, assessment strategies, student-centric approach, and study cost

Active Learning Attributes
Computer programs, computer-
based training, virtual learning
environment, and simulators

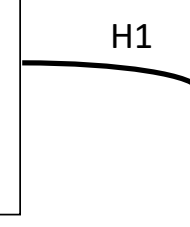


The Dependent Variable is the Graduate Readiness for Employability consisting of:

- Soft skills: (Adnan, Daud, Alias, \& Razali, 2017; Al-Azri, 2016; Anastasiu et al., 2017; Belwal et al., 2017; Craps et al., 2017; Evans, Davis, \& Wheeler, 2017; Finch, Hamilton, Baldwin, \& Zehner, 2013; Gupta, Singh, \& Kaushik, 2018; Lane, 2017; Moore \& Morton, 2017; Neisler, Clayton, Al-Barwani, Al Kharusi, \& Al-Sulaimani, 2016)

- Technical skills: (Al-Lamki, 1998, 2006; Al-Mahrooqi, 2012; Al-Mahrooqi \& Denman, 2016; Allen \& De Weert, 2007; Arkoudis, Baik, Bexley, \& Doughney, 2014; Manoharan \& Arockiam, 2017).

- Proficiency of English (Al-Lamki, 1998, 2006; Al-Mahrooqi, 2012; Al-Mahrooqi \& Denman, 2016; Allen \& De Weert, 2007; Arkoudis, Baik, Bexley, \& Doughney, 2014; Manoharan \& Arockiam, 2017)

The moderating Variable of this study is Gender and Career and Moral Mindset (Mansour, 2018; Suleman, 2018; Strachan, Peixoto, Emembolu, \& Restivo, 2018; Turen, 2015; Rangel, 2018; Lewis \& McKenzie, 2017; Balakrishnan \& Low, 2016; Taliaferro, 2018; Brewer, 2018; Rozan \& Zibarzani, 2018).

\section{Hypothesis Development}

The study used alternative form hypothesis in the following hypothesis:

Hypothesis 1: There is a significant relationship between human capital attributes and graduate readiness for employability

Hypothesis 2: There is a significant relationship between Social capital attributes and graduates attainment of readiness for employability skills.

Hypothesis 3: There is significant relationship between individual attributes and graduates attainment of readiness for employability skills.

Hypothesis 4: Institutions related attributes affect significantly graduates attainment of readiness for employability skills.

Hypothesis 5: Smart Active teaching environment enhances positively the Graduate Readiness for employability technical skills.

Hypothesis 6: Gender, Career and Moral Mindset of the Engineering graduates have high impact in the attainment of Graduate Readiness for employability skills and consequently affect the graduates attributing factors.

\section{CONCLUSION AND RECOMMENDATIONS}

As the main objectives of the current study is to determine a Graduate Readiness for the Employability framework for Omani Engineering graduates. Specifically, this study intends to measure the level of readiness of Engineering Graduates for Employability in the HEIs in Oman, to determine the influencing factors that contribute to the readiness of Engineering Graduates for Employability in the HEIs in Oman, and to measure the moderating effects of Gender, Career mindset and Moral mindset on the relationship between Influencing factors in the readiness of Engineering Graduates for Employability in the HEIs in Oman.

Since there has been a big investment to provide quality higher educational institutes capable of providing suitable graduates to fulfill the requirements of the labor market for both public and private sectors. Therefore, graduates' readiness for employability has become a major 
issue for HEIs in Oman due to the growing concern from governments and industries on the quality of the graduates. As a result, by conducting a systematic research review formality of the recent literature aiming to identify the key graduates' readiness for employability skills, the most influential graduates' attributes factors, and the essential moderating variables, and academic readiness for employability framework is designed to enhance the acquirement of readiness for employability skills that can be used as a guideline by the higher education institutes in Oman to enhance the quality of its graduates.

Based on the above findings, the study develops a graduate readiness for employability framework which analyses the effects of influential factors on the graduate readiness for employability that will be considered as an empirical study on the graduates of the engineering colleges in Oman. This study further empirically tests the factors which influence the graduate readiness for employability and its relationship with gender, moral mindset, and career mindset of the Omani engineering colleges' students. The results of the study will fill the gap in understanding the main factors affecting the attainment of graduates' readiness for employability skills in Oman. The determined framework can be further analyzed and tested. The result can be used by graduates to increase their readiness for employability, HEIs, other prospective academics, and policymakers can also use it to improve academic curricula, promote employability requirements, and appropriate policies to produce graduates ready for work. Finally, the study recommends justifying this conceptual framework by empirical data from the Engineering Graduate in the Higher Education Institutes (HEIs) and drawing a policy guideline for ensuring of readiness of engineering graduates for employability in the HEIs in Oman.

\section{REFERENCES}

Abdullah-Al-Mamun, M. (2012). The soft skills education for the vocational graduate: Value as work readiness skills. British Journal of Education, Society \& Behavioural Science, 2(4), 326-338.

Adams, W. K., Reid, S., LeMaster, R., McKagan, S. B., Perkins, K. K., Dubson, M., \& Wieman, C. E. (2008). A study of educational simulations part I-Engagement and learning. Journal of Interactive Learning Research, 19(3), 397-419.

Adnan, Y. M., Daud, M. N., Alias, A., \& Razali, M. N. (2017). Importance of soft skills for graduates in the real estate programmes in Malaysia. Journal of Surveying, Construction and Property, 3(2).

Ajwad, M. I., Hut, S., Abdulloev, I., Audy, R., de Laat, J., Kataoka, S., . . Torracchi, F. (2014). The skills road: skills for employability in Tajikistan.

Al-Azri, A. K. H. (2016). Academics', students', employers', and graduates' perceptions towards business management and administration undergraduate employability: implications for higher education and industry in Oman. Brunel University London.

Al-Harthi, H. K. (2011). University student perceptions of the relationship between university education and the labour market in Egypt and Oman. Prospects, 41(4), 535-551.

Al-Lamki, S. M. (1998). Barriers to Omanization in the private sector: The perceptions of Omani graduates. International Journal of Human resource management, 9(2), 377-400.

Al-Lamki, S. M. (2002). Higher education in the Sultanate of Oman: The challenge of access, equity and privatization. Journal of Higher Education Policy and Management, 24(1), 75-86.

Al-Lamki, S. M. (2006). The development of private higher education in the Sultanate of Oman: Perception and analysis. International Journal of Private Education, 1(1), 54-77. 
Al-Mahrooqi, R. (2012). English Communication Skills: How Are They Taught at Schools and Universities in Oman? English Language Teaching, 5(4), 124-130.

Al-Mahrooqi, R., \& Denman, C. J. (2016). Omani graduates' English-language communication skills in the workforce: Employees' perspectives. International Journal of Applied Linguistics and English Literature, 5(4), 172-182.

Al-Marjan, H. (2004). Educational challenges in Oman and Omanisation. Oman Observer.

Allen, J., \& De Weert, E. (2007). What do educational mismatches tell us about skill mismatches? A cross-country analysis. European Journal of Education, 42(1), 59-73.

Anastasiu, L., Anastasiu, A., Dumitran, M., Crizboi, C., Holmaghi, A., \& Roman, M. (2017). How to Align the University Curricula with the Market Demands by Developing Employability Skills in the Civil Engineering Sector. Education Sciences, 7(3), 74.

Ansari, I., \& McGlade, J. (2018). Omanisation, Youth Employment and SME Firms in Oman The Future of Labour Market Reform in the Gulf Region: Towards a Multi-Disciplinary, Evidence-Based and Practical Understanding (pp. 55): Gerlach Press.

Arkoudis, S., Baik, C., Bexley, E., \& Doughney, L. (2014). English language proficiency and employability framework: Melbourne: Centre for the Study of Higher Education.

Arthur Lazarus, M. (2013). Soften up: the importance of soft skills for job success. Physician executive, 39(5), 40.

Belwal, R., Priyadarshi, P., \& Al Fazari, M. H. (2017). Graduate attributes and employability skills: Graduates' perspectives on employers' expectations in Oman. International Journal of Educational Management, 31(6), 814-827.

Blom, A., \& Saeki, H. (2011). Employability and skill set of newly graduated engineers in India: The World Bank.

Boyd, J. L. (2017). Interactive simulations: Improving learning retention in knowledge-based online training courses. Capella University.

Breton, T. R. (2012). The role of education in economic development: theory, history, and current returns.

Brewer, A. M. (2018). Factors Influencing Career Encountering, Experiencing and Shaping Careers (pp. 67-105): Springer.

Bridgstock, R. (2009). The graduate attributes we've overlooked: Enhancing graduate employability through career management skills. Higher Education Research \& Development, 28(1), 31-44.

Chan, C. K., Fong, E. T., Luk, L. Y., \& Ho, R. (2017). A review of literature on challenges in the development and implementation of generic competencies in higher education curriculum. International Journal of Educational Development, 57, 1-10.

Chaturvedi, A., Yadav, A., \& Bajpai, S. (2011). Communicative approach to soft and Hard skills. Journal VSRD-International of bussiness \& management research, 1(1).

Clarke, M. (2018). Rethinking graduate employability: The role of capital, individual attributes and context. Studies in Higher Education, 43(11), 1923-1937.

Coenjaerts, C., Ernst, C., Fortuny, M., Rei, D., \& Pilgrim, I. M. (2009). Youth employment. Promoting Pro-Poor Growth, 119.

Conrad, D. L. (2008). From community to community of practice: Exploring the connection of online learners to informal learning in the workplace. The Amer. Jrnl. of Distance Education, 22(1), 3-23.

Cooper, W., Gallagher, G., Collins, T., \& Shahir, T. (2015). How will the GCC close the skills gap? : EY: Building a better working World. 
Craps, S., Pinxten, M., Saunders, G., Leandro Cruz, M., Gaughan, K., \& Langie, G. (2017). Professional Roles and Employability of Future Engineers.

de Janasz, S., Forret, M., Haack, D., \& Jonsen, K. (2013). Family status and work attitudes: An investigation in a professional services firm. British Journal of Management, 24(2), 191210.

Deepa, S., \& Seth, M. (2013). Do soft skills matter?-Implications for educators based on recruiters' perspective. IUP Journal of Soft Skills, 7(1), 7.

Evans, S. G., Davis, J., \& Wheeler, M. (2017). An Analysis of School-to-Work Readiness. Saint Louis University.

E-Census. (2020). The Arabian Stories, Over 65,000 job seekers in Oman: E-Census survey. Retrieved from https://www.thearabianstories.com/2020/12/15/over-65000-job-seekersin-oman-e-census-survey/

Finch, D. J., Hamilton, L. K., Baldwin, R., \& Zehner, M. (2013). An exploratory study of factors affecting undergraduate employability. Education+ Training, 55(7), 681-704.

Fitzgerald, G., Mitchem, K., Hollingsead, C., Miller, K., Koury, K., \& Tsai, H.-H. (2011). Exploring the bridge from multimedia cases to classrooms: Evidence of transfer. Journal of Special Education Technology, 26(2), 23-38.

Forret, M. L., \& Dougherty, T. W. (2004). Networking behaviors and career outcomes: differences for men and women? Journal of Organizational Behavior: The International Journal of Industrial, Occupational and Organizational Psychology and Behavior, 25(3), 419-437.

Fugate, M., \& Ashforth, B. E. (2003). Employability: The construct, its dimensions, and applications. Paper presented at the Academy of Management Proceedings.

Fugate, M., Kinicki, A. J., \& Ashforth, B. E. (2004). Employability: A psycho-social construct, its dimensions, and applications. Journal of vocational behavior, 65(1), 14-38.

Funsch, L. P. (2015). Oman Reborn: Balancing Tradition and Modernization: Springer.

Gupta, T., Singh, A., \& Kaushik, A. (2018). Placement Predict: A Review of Engineering Graduate Placement Statistics in India. International Journal of Engineering Science, 16381.

Hassan, N. F., \& Puteh, S. (2017). A Survey of Technology Enabled Active Learning in Teaching and Learning Practices to Enhance the Quality of Engineering Students. Advanced Science Letters, 23(2), 1104-1108.

Heijde, C. M. V. D., \& Van Der Heijden, B. I. (2006). A competence-based and multidimensional operationalization and measurement of employability. Human Resource Management: Published in Cooperation with the School of Business Administration, The University of Michigan and in alliance with the Society of Human Resources Management, 45(3), 449-476.

Hinchliffe, G. W., \& Jolly, A. (2011). Graduate identity and employability. British Educational Research Journal, 37(4), 563-584.

Holmes, L. (2013). Competing perspectives on graduate employability: possession, position or process? Studies in Higher Education, 38(4), 538-554.

Hurrell, S. A., \& Scholarios, D. (2014). The People Make the Brand" Reducing Social Skills Gaps Through Person-Brand Fit and Human Resource Management Practices. Journal of Service Research, 17(1), 54-67.

Jackson, D. (2014). Factors influencing job attainment in recent Bachelor graduates: evidence from Australia. Higher Education, 68(1), 135-153. 
Jackson, D. (2016). Skill mastery and the formation of graduate identity in Bachelor graduates: evidence from Australia. Studies in Higher Education, 41(7), 1313-1332.

Jones, M. T. (2017). Mindset and Behavior Strategies and the Effect on College and Career Readiness: Trevecca Nazarene University.

Joshi, V., \& Ghosal, S. (2009). Impact of foreign direct investment on employment in Oman. Paper presented at the Conference of The International Journal Of Arts And Sciences. 1 (18).

Kalfa, S., \& Taksa, L. (2015). Cultural capital in business higher education: reconsidering the graduate attributes movement and the focus on employability. Studies in Higher Education, 40(4), 580-595.

Kapp, K. M. (2012). The gamification of learning and instruction: Wiley San Francisco.

Lane, A. (2017). The systemic implications of constructive alignment of higher education level learning outcomes and employer or professional body based competency frameworks.

Lim, Y.-M., Lee, T. H., Yap, C. S., \& Ling, C. C. (2016). Employability skills, personal qualities, and early employment problems of entry-level auditors: Perspectives from employers, lecturers, auditors, and students. Journal of Education for Business, 91(4), 185-192.

Liska, A. E. (1984). A critical examination of the causal structure of the Fishbein/Ajzen attitudebehavior model. Social psychology quarterly, 61-74.

Manoharan, S., \& Arockiam, K. (2017). A Study on the Influence of Domicile of Engineering Colleges and Competency Profile of Industrial Aspirants. International Journal of Engineering and Management Research (IJEMR), 7(3), 238-241.

Mansour, S. (2018). Spatial Patterns of Female Labor Force Participation in Oman: A GIS-Based Modeling. The Professional Geographer, 70(4), 593-608.

Messum, D. G., Wilkes, L. M., Jackson, D., \& Peters, K. (2016). Employability Skills in Health Services Management: perceptions of recent graduates. Asia-Pacific Journal of Health Management, 11(1), 25-34.

Moore, T., \& Morton, J. (2017). The myth of job readiness? Written communication, employability, and the 'skills gap'in higher education. Studies in Higher Education, 42(3), 591-609.

NCSI. (2015). Statistical Year Book: NCSI Muscat, Oman.

NCSI. (2017). Statistical Year Book. In: NCSI Muscat, Oman.

Neisler, O., Clayton, D., Al-Barwani, T., Al Kharusi, H., \& Al-Sulaimani, H. (2016). 21st century teacher education: Teaching, learning and assessment of critical thinking skills at Sultan Qaboos University. Redefining Teacher Education for the Post-2015 Era: Global Challenges and Best Practices, 77-95.

Okay-Somerville, B., \& Scholarios, D. (2014). Coping with career boundaries and boundarycrossing in the graduate labour market. Career Development International, 19(6), 668682.

Okay-Somerville, B., \& Scholarios, D. (2015). Career Self-Management, Perceived Employability, and Employment Success during University-to-Work Transitions: A Social Cognitive Career Theory Perspective. Zarzadzanie Zasobami Ludzkimi(2015 6 (107) Employability (Zatrudnialność), 33-60.

OMAN, S. O. (2011). Quality of higher education in 21st century-a case of Oman. Journal of educational and instructional studies in the world, 9.

Parsons, T. (2008). Definition: soft skills. 
Randeree, K. (2009). Strategy, Policy and Practice in the Nationalisation of Human Capital:'Project Emiratisation.'. Research \& Practice in Human Resource Management, $17(1)$.

Rao, M. (2018). Soft skills: toward a sanctimonious discipline. On the Horizon, 26(3), 215-224.

Rothwell, A., Herbert, I., \& Rothwell, F. (2008). Self-perceived employability: Construction and initial validation of a scale for university students. Journal of vocational behavior, 73(1), $1-12$.

Rozan, M. Z. A., \& Zibarzani, M. (2018). A Study of Entrepreneurial Mindset through the Dual Sided Role as Service Seeker and Service Provider among University Students. Pertanika Journal of Social Sciences \& Humanities, 26(4).

Schultz, T. (1963). The Economics Value of Education . New York and London. Columbia: University Press.

Shetty, D., \& Xu, J. (2018). Strategies to Address "Design Thinking” in Engineering Curriculum. Paper presented at the ASME 2018 International Mechanical Engineering Congress and Exposition.

Slaughter, S., Taylor, B. J., \& Rosinger, K. O. (2015). A critical reframing of human capital theory in US higher education. Critical approaches to the study of higher education: A practical introduction, 80-102.

Smith, C., Ferns, S., \& Russell, L. (2014). Conceptualising and measuring'employablity'-lessons from a National OLT Project. Paper presented at the http://acen. edu. au/2014conference-proceedings/.

Stiwne, E. E., \& Alves, M. G. (2010). Higher education and employability of graduates: will Bologna make a difference? European Educational Research Journal, 9(1), 32-44.

Strachan, R., Peixoto, A., Emembolu, I., \& Restivo, M. T. (2018). Women in engineering: Addressing the gender gap, exploring trust and our unconscious bias. Paper presented at the 2018 IEEE Global Engineering Education Conference (EDUCON).

Sumanasiri, E. G. T., Yajid, M. S. A., \& Khatibi, A. (2015). Conceptualizing Learning and Employability" Learning and Employability Framework". Journal of Education and Learning, 4(2), 53-63.

Swailes, S., Al Said, L., \& Al Fahdi, S. (2012). Localisation policy in Oman: a psychological contracting interpretation. International journal of public sector management, 25(5), 357372.

Vanhercke, D., De Cuyper, N., Peeters, E., \& De Witte, H. (2014). Defining perceived employability: a psychological approach. Personnel Review, 43(4), 592-605.

Yang, H., Cheung, C., \& Fang, C. C. (2015). An empirical study of hospitality employability skills: perceptions of entry-level hotel staff in China. Journal of Hospitality \& Tourism Education, 27(4), 161-170.

\section{Copyrights}

Copyright for this article is retained by the author(s), with first publication rights granted to the journal. This is an open-access article distributed under the terms and conditions of the Creative Commons Attribution license (http://creativecommons.org/licenses/by/4.0/). 